\title{
Injury mortality among children and teenagers in New Zealand compared with the United States of America
}

\author{
John D Langley, Judith Smeijers
}

\begin{abstract}
Objectives-New Zealand (NZ) has an unenviable track record in childhood injury mortality. We sought to describe this burden and to compare it with the United States of America (USA), with a view to taking the first step in identifying potential areas in which NZ might benefit from injury control as practiced in the USA.
\end{abstract}

Methods-We identified all children and teenagers who had died of injury for the period 1984-93 from the NZ Health Information Service mortality data files. We compared their rates of injury with previously published rates for USA.

Results-The age specific rates follow a J shaped distribution, with high rates in the first year of life followed by a decline to the lowest rate, among 5-9 year olds, a marginally higher rate among 10-14 year olds, and a dramatic rise among those in the 15-19 age group. The specific causes of death vary considerably by age group. NZ's overall rate of child and adolescent injury is not substantially different from that of the USA, but marked differences are apparent when examining cause specific rates.

Conclusions-In terms of the theoretical potential to reduce the total injury mortality rate, priority must be given to 15-19 year olds who account for $61 \%$ of all NZ injury deaths. Priorities for this age group are: motor vehicle traffic crashes (especially those involving occupants and motorcyclists), and suicide. Among the children, priorities are: pedestrian and occupant deaths, and drownings. Among infants, the priority is suffocation.

(Injury Prevention 1997; 3: 195-199)

Keywords: mortality; injury matrix.

In 1996, Injury Prevention published the first of what is hoped will be a regular series on childhood injury mortality statistics for children and adolescents in the United States of America (USA). ${ }^{1}$ Accompanying that paper was an editorial note expressing the hope that the journal would be able to publish similar data from other countries as international comparisons are vital to the promotion of injury prevention.

New Zealand (NZ) has an unenviable track record in childhood mortality and, in particular, childhood injury mortality. We sought to describe the latter burden and to compare it with the USA, with a view to identifying potential areas where NZ might benefit from injury control practice in the USA.

\section{Methods}

We identified all children and teenagers who had died of injury for the period 1984-93 from the NZ Health Information Service mortality data files. Given NZ's population of 3.5 million, we used data for 10 years to produce stable estimates for the purposes of making comparisons with the USA statistics.

To facilitate comparisons we used the proposed basic tables for describing injury mortality data recently recommended by the injury control community in the USA ( $E$ McLoughlin et al, National Center for Injury Prevention and Control, 1995; unpublished) and the age groups used in the recent summary of childhood injury mortality data in the USA. ${ }^{1}$ Population estimates, as at 30 June were obtained for each year from Statistics New Zealand. Rate ratios were derived for NZ compared with the USA, using the rates presented by Fingerhut and others.

For motor vehicle traffic crashes (MVTs) in which the road user was unspecified (International Classification of Diseases (ICD) subcategory 0.9 ) we reviewed the 90 character narrative on the circumstances of injury provided on the electronic record with a view to reclassifying them. Reclassification was possible because the precision required for the 'proposed basic tables' was less than that required within ICD. For example, the 'proposed basic tables' have a category for motorcyclist, whereas ICD requires a determination of whether the motorcyclist was the driver or pillion passenger. If that could not be determined, then under ICD rules, a person described only as a motorcyclist would be classified as an 'unspecified road user'.

\section{Results}

Table 1 presents the deaths according to major injury groupings by age group. The age specific rates follow a J shaped distribution, with high rates in the first year of life followed by a decline to the lowest rate among 5-9 year olds, a marginally higher rate among 10-14 year olds, and a dramatic rise among those in the $15-19$ age group.

The specific causes of death vary considerably by age group. The small number of deaths for those under 1 year precludes the estimation of reliable rates in several instances. Unintentional suffocation accounts for $41 \%$ of all deaths in this age group and the rate exceeds 
those for all other age groups by a considerable margin.

Among the 1-4 year olds, drownings, pedestrian, and occupant MVT injuries exhibit the highest rates. These three categories account for $56 \%$ of all the deaths in this age group.

A similar pattern is evident for 5-9 and 1014 year olds, but the rates are not as high, especially for drowning. In both age groups, MVTs account for approximately $50 \%$ of all deaths.

The $15-19$ year age group contributed $61 \%$ of the child and adolescent mortality. Sixty two per cent of the injury deaths within this age group were due to MVTs. Their rates of occupant and motorcycle deaths were the highest age specific and cause specific rates, This age group also has a high rate of suicide (all methods).

\section{NZ COMPARED WITH USA}

Unintentional injuries accounted for $83 \%$ of a injury deaths followed by suicide $13 \%$ an $\frac{}{6}$ homicide $4 \%$. This contrasts with the USA where these percentages were as follows unintentional $64 \%$, homicide $24 \%$, and suicide $11 \%{ }^{1}$

The four leading specific causes of death in

Table 1 Injury deaths and rates among children and teenagers in New Zealand 1984-93

\begin{tabular}{|c|c|c|c|c|c|c|c|c|c|c|c|c|c|}
\hline & \multirow[b]{2}{*}{$E$ code } & \multicolumn{2}{|l|}{$0-19$} & \multicolumn{2}{|l|}{$<1$ year } & \multicolumn{2}{|c|}{$1-4$ years } & \multicolumn{2}{|c|}{$5-9$ years } & \multicolumn{2}{|c|}{$10-14$ years } & \multicolumn{2}{|c|}{ 15-19 years } \\
\hline & & Deaths & Rate $^{\star *}$ & Deaths & Rate $^{\star \star}$ & Deaths & Rate** & Deaths & Rate $^{\star \star}$ & Deaths & Rate $^{* *}$ & Deaths & Rate $^{\star}$ \\
\hline All external causes & E800-E999 & 3643 & 33.7 & 185 & 33.2 & 512 & 23.9 & 312 & 12.2 & 397 & 14.9 & 2237 & 76.9 \\
\hline $\begin{array}{l}\text { Motor vehicle traffic } \\
\text { Unintentional } \\
\text { Person injured }\end{array}$ & $\begin{array}{l}\text { (MVT) } \\
\text { E810-E819 } \\
\text { (4th digit code) }\end{array}$ & 1935 & 17.9 & 30 & 5.4 & 169 & 7.9 & 165 & 6.5 & 186 & 7.0 & 1385 & 47.6 \\
\hline $\begin{array}{l}\text { Occupant } \\
\text { Motorcyclist } \\
\text { Pedal cyclist } \\
\text { Pedestrian } \\
\text { Unspecified }\end{array}$ & $\begin{array}{l}.0, .1 \\
.2, .3 \\
.6 \\
.7 \\
.9\end{array}$ & $\begin{array}{r}1154 \\
336 \\
104 \\
317 \\
17\end{array}$ & $\begin{array}{l}10.8 \\
3.2 \\
1.0 \\
2.9 \\
\dagger\end{array}$ & $\begin{array}{r}30 \\
0 \\
0 \\
0 \\
0\end{array}$ & $\begin{array}{l}5.4 \\
\star \\
\star \\
\star \\
\dagger\end{array}$ & $\begin{array}{r}73 \\
0 \\
3 \\
90 \\
1\end{array}$ & $\begin{array}{c}3.4 \\
\star \\
\star \\
4.2 \\
\dagger\end{array}$ & $\begin{array}{r}59 \\
0 \\
25 \\
79 \\
1\end{array}$ & $\begin{array}{l}2.3 \\
\star \\
1.0 \\
3.1 \\
\dagger\end{array}$ & $\begin{array}{r}95 \\
5 \\
42 \\
41 \\
1\end{array}$ & $\begin{array}{l}3.6 \\
0.2 \\
1.6 \\
1.5 \\
\dagger\end{array}$ & $\begin{array}{r}897 \\
331 \\
34 \\
107 \\
14\end{array}$ & $\begin{array}{c}31.1 \\
11.5 \\
1.2 \\
3.7 \\
\dagger\end{array}$ \\
\hline MVT, all & +E958.5, E988.5 & 1935 & 17.9 & 30 & 5.4 & 169 & 7.9 & 165 & 6.5 & 186 & 7.0 & 1385 & 47.6 \\
\hline Pedestrian, other & $\begin{array}{l}\text { E800-E807 (.2), } \\
\text { E820-E825 (.7), } \\
\text { E826-E829 (.0) }\end{array}$ & 77 & 0.7 & 3 & * & 42 & 2.0 & 6 & $\star$ & 10 & 0.4 & 16 & 0.5 \\
\hline $\begin{array}{l}\text { Firearm, all } \\
\text { Unintentional } \\
\text { Suicide } \\
\text { Homicide }\end{array}$ & $\begin{array}{l}\text { E922 } \\
\text { E955 (.0-.4) } \\
\text { E965 (.0-.4), } \\
\text { E970 }\end{array}$ & $\begin{array}{r}137 \\
31 \\
84 \\
17\end{array}$ & $\begin{array}{l}1.3 \\
0.3 \\
0.8 \\
0.2\end{array}$ & $\begin{array}{c}1 \\
1 \\
\text { NA } \\
0\end{array}$ & $\stackrel{\star}{\star} \underset{\star}{*}$ & $\begin{array}{r}3 \\
1 \\
\mathrm{NA} \\
2\end{array}$ & $\underset{\star}{\stackrel{\star}{*}}$ & $\begin{array}{l}8 \\
4 \\
0 \\
4\end{array}$ & $\begin{array}{l}0.3 \\
\star \\
\star \\
\star\end{array}$ & $\begin{array}{r}18 \\
10 \\
3 \\
5\end{array}$ & $\begin{array}{l}0.7 \\
0.4 \\
\star \\
0.2\end{array}$ & $\begin{array}{r}107 \\
15 \\
81 \\
6\end{array}$ & $\begin{array}{l}3.7 \\
0.5 \\
2.8 \\
0.2\end{array}$ \\
\hline Intent unknown & E985 (.0-.4) & 5 & 0.0 & 0 & * & 0 & * & 0 & $\star$ & 0 & * & 5 & 0.2 \\
\hline $\begin{array}{l}\text { Drowning } \\
\text { Unintentional }\end{array}$ & $\begin{array}{l}\text { E830, E832, } \\
\text { E910 }\end{array}$ & 327 & 3.0 & 4 & $\star$ & 125 & 5.8 & 44 & 1.7 & 39 & 1.5 & 115 & 4.0 \\
\hline All & $\begin{array}{l}+\mathrm{E} 954, \mathrm{E} 964, \\
\text { E984 }\end{array}$ & 335 & 3.1 & 4 & * & 125 & 5.8 & 45 & 1.8 & 39 & 1.5 & 122 & 4.2 \\
\hline $\begin{array}{l}\text { Fire/flame } \\
\text { Unintentional } \\
\text { All }\end{array}$ & $\begin{array}{l}\text { E890-E899 } \\
\text { +E958.1, } \\
\text { E968.0, E988.1 }\end{array}$ & $\begin{array}{l}93 \\
99\end{array}$ & $\begin{array}{l}0.9 \\
0.9\end{array}$ & $\begin{array}{l}7 \\
9\end{array}$ & $\begin{array}{l}1.3 \\
1.6\end{array}$ & $\begin{array}{l}40 \\
41\end{array}$ & $\begin{array}{l}1.9 \\
1.9\end{array}$ & $\begin{array}{l}16 \\
16\end{array}$ & $\begin{array}{l}0.6 \\
0.6\end{array}$ & $\begin{array}{l}8 \\
8\end{array}$ & $\begin{array}{l}0.3 \\
0.3\end{array}$ & $\begin{array}{l}22 \\
25\end{array}$ & $\begin{array}{l}0.8 \\
0.9\end{array}$ \\
\hline \multicolumn{2}{|l|}{$\begin{array}{l}\text { Suffocation, all } \\
\text { Unintentional }\end{array}$} & 391 & 3.6 & 81 & 14.5 & 29 & 1.4 & 10 & 0.4 & 49 & 1.8 & 222 & 7.6 \\
\hline $\begin{array}{l}\text { Inhalation/ } \\
\text { ingestion }\end{array}$ & E911-E912 & 48 & 0.4 & 29 & 5.2 & 12 & 0.6 & 1 & * & 2 & $\star$ & 4 & * \\
\hline $\begin{array}{l}\text { Other } \\
\text { Suicide } \\
\text { Homicide } \\
\text { Intent unknown }\end{array}$ & $\begin{array}{l}\text { E913 } \\
\text { E953 } \\
\text { E963 } \\
\text { E983 }\end{array}$ & $\begin{array}{r}92 \\
236 \\
8 \\
7\end{array}$ & $\begin{array}{l}0.9 \\
2.2 \\
0.1 \\
0.1\end{array}$ & $\begin{array}{c}48 \\
\text { NA } \\
4 \\
0\end{array}$ & $\begin{array}{l}8.6 \\
\text { NA } \\
0.7 \\
\star\end{array}$ & $\begin{array}{c}17 \\
\text { NA } \\
0 \\
0\end{array}$ & 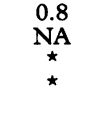 & $\begin{array}{l}5 \\
2 \\
2 \\
0\end{array}$ & $\begin{array}{l}0.2 \\
\star \\
\star \\
\star\end{array}$ & $\begin{array}{r}16 \\
26 \\
0 \\
5\end{array}$ & $\begin{array}{l}0.6 \\
1.0 \\
\star \\
0.2\end{array}$ & $\begin{array}{r}6 \\
208 \\
2 \\
2\end{array}$ & $\begin{array}{l}0.2 \\
7.1 \\
\star \\
\star\end{array}$ \\
\hline Fall, unintentional & $\begin{array}{l}\text { E880-E886, } \\
\text { E888 }\end{array}$ & 77 & 0.7 & 5 & 0.9 & 16 & 0.7 & 10 & 0.4 & 8 & 0.3 & 38 & 1.3 \\
\hline All & $\begin{array}{l}\text { +E957, E968.1 } \\
\text { E987 }\end{array}$ & 95 & 0.9 & 5 & 0.9 & 17 & 0.8 & 11 & 0.4 & 10 & 0.4 & 52 & \\
\hline $\begin{array}{l}\text { Cutting/piercing } \\
\text { Homicide } \\
\text { All }\end{array}$ & $\begin{array}{l}\text { E966, E974 } \\
+ \text { E920, E956, } \\
\text { E986 }\end{array}$ & $\begin{array}{l}33 \\
42\end{array}$ & $\begin{array}{l}0.3 \\
0.4\end{array}$ & $\begin{array}{l}1 \\
1\end{array}$ & $\stackrel{\star}{\star}$ & $\begin{array}{l}8 \\
9\end{array}$ & $\begin{array}{l}0.4 \\
0.4\end{array}$ & $\begin{array}{l}4 \\
9\end{array}$ & $\stackrel{\star}{\star}$ & $\begin{array}{l}5 \\
6\end{array}$ & $\begin{array}{l}0.2 \\
0.2\end{array}$ & $\begin{array}{l}15 \\
17\end{array}$ & $\begin{array}{l}0.5 \\
0.6\end{array}$ \\
\hline $\begin{array}{l}\text { Poisoning, all } \\
\text { Unintentional } \\
\text { Suicide } \\
\text { Homicide } \\
\text { Intent unknown }\end{array}$ & $\begin{array}{l}\text { E850-E869 } \\
\text { E950-E952 } \\
\text { E962, E972 } \\
\text { E980-E982 }\end{array}$ & $\begin{array}{r}183 \\
50 \\
108 \\
2 \\
23\end{array}$ & $\begin{array}{l}1.7 \\
0.5 \\
1.0 \\
\star \\
0.2\end{array}$ & $\begin{array}{c}2 \\
2 \\
\text { NA } \\
0 \\
0\end{array}$ & 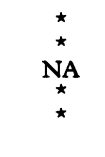 & $\begin{array}{r}8 \\
8 \\
\text { NA } \\
0 \\
0\end{array}$ & $\begin{array}{l}0.4 \\
0.4 \\
\text { NA } \\
\star \\
\star\end{array}$ & $\begin{array}{l}3 \\
1 \\
1 \\
1 \\
0\end{array}$ & $\begin{array}{l}\star \\
\star \\
\star \\
\star \\
\star\end{array}$ & $\begin{array}{r}21 \\
9 \\
9 \\
1 \\
2\end{array}$ & $\begin{array}{l}0.8 \\
0.3 \\
0.3 \\
\star \\
\star\end{array}$ & $\begin{array}{r}149 \\
30 \\
98 \\
0 \\
21\end{array}$ & $\begin{array}{l}5.1 \\
1.0 \\
3.4 \\
\star \\
0.7\end{array}$ \\
\hline $\begin{array}{l}\text { All } \\
\text { Unintentional } \\
\text { Suicide } \\
\text { Homicide } \\
\text { Intent unknown/ } \\
\text { other }\end{array}$ & $\begin{array}{l}\text { E800-E949 } \\
\text { E950-E959 } \\
\text { E960-E978 } \\
\text { E980-E999 }\end{array}$ & $\begin{array}{r}3013 \\
456 \\
132 \\
42\end{array}$ & $\begin{array}{r}27.8 \\
4.2 \\
1.2 \\
0.4\end{array}$ & $\begin{array}{r}157 \\
\text { NA } \\
27 \\
1\end{array}$ & 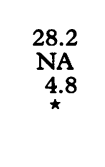 & $\begin{array}{c}480 \\
\text { NA } \\
31 \\
1\end{array}$ & $\begin{array}{c}22.4 \\
\text { NA } \\
1.4 \\
\star\end{array}$ & $\begin{array}{r}294 \\
3 \\
15 \\
0\end{array}$ & $\begin{array}{c}11.5 \\
\star \\
\star \\
\star\end{array}$ & $\begin{array}{r}335 \\
41 \\
14 \\
7\end{array}$ & $\begin{array}{r}12.6 \\
1.5 \\
0.5 \\
0.3\end{array}$ & $\begin{array}{r}1747 \\
412 \\
45 \\
33\end{array}$ & $\begin{array}{r}60.0 \\
14.2 \\
1.5 \\
1.1 \\
\end{array}$ \\
\hline \multicolumn{2}{|c|}{ Person years of exposure } & 10819600 & & 556982 & & 2140338 & & 2551060 & & 2661490 & & 2909730 & \\
\hline
\end{tabular}

* Rates based on fewer than five deaths are unstable and an asterisk is shown in place of a rate.

†The free text description of the injury event shows that most of the unspecified (.9) traffic deaths involve vehicle occupants or motorcyclists. Therefore, in the calculation of rates, the 4th digit .9 codes were distributed according to the free text information for each age group. 
Table 2 Rate ratio for child and teenage injury deaths, NZ compared with the USA

\begin{tabular}{|c|c|c|c|c|c|c|c|c|c|c|c|c|c|}
\hline & \multirow[b]{2}{*}{ E code } & \multicolumn{2}{|c|}{$0-19$ years } & \multicolumn{2}{|c|}{$<1$ year } & \multicolumn{2}{|c|}{$1-4$ years } & \multicolumn{2}{|c|}{$5-9$ years } & \multicolumn{2}{|c|}{$10-14$ years } & \multicolumn{2}{|c|}{$15-19$ years } \\
\hline & & $\begin{array}{l}\text { Rate } \\
\text { ratio }\end{array}$ & $95 \% C I$ & $\begin{array}{l}\text { Rate } \\
\text { ratio }\end{array}$ & $95 \% C I$ & $\begin{array}{l}\text { Rate } \\
\text { ratio }\end{array}$ & $95 \% C I$ & $\begin{array}{l}\text { Rate } \\
\text { ratio }\end{array}$ & $95 \% C I$ & $\begin{array}{l}\text { Rate } \\
\text { ratio }\end{array}$ & $95 \% C I$ & $\begin{array}{l}\text { Rate } \\
\text { ratio }\end{array}$ & $95 \% C I$ \\
\hline All external causes & E800-E999 & 1.19 & 1.15 to 1.23 & 1.00 & 0.86 to 1.39 & 1.22 & 1.11 to 1.34 & 1.25 & 1.11 to 1.41 & 1.03 & 0.93 to 1.14 & 1.10 & 1.05 to 1.15 \\
\hline $\begin{array}{l}\text { Motor vehicle traffi } \\
\text { Unintentional } \\
\text { Person injured }\end{array}$ & $\begin{array}{l}\text { ic (MVT) } \\
\text { E810-E819 } \\
\text { (4th digit codes) }\end{array}$ & 1.72 & 1.64 to 1.81 & 1.15 & 0.78 to 2.53 & 1.65 & 1.39 to 1.95 & 1.43 & 1.21 to 1.69 & 1.24 & 1.06 to 1.45 & 1.69 & 1.59 to 1.79 \\
\hline $\begin{array}{l}\text { Occupant } \\
\text { Motorcyclist } \\
\text { Pedal cyclist } \\
\text { Pedestrian } \\
\text { Unspecified }\end{array}$ & $\begin{array}{l}.0, .1 \\
.2, .3 \\
.6 \\
.7 \\
.9\end{array}$ & $\begin{array}{l}1.35 \\
7.85 \\
2.02 \\
1.91 \\
+\end{array}$ & $\begin{array}{l}1.27 \text { to } 1.44 \\
6.72 \text { to } 9.18 \\
1.62 \text { to } 2.52 \\
1.69 \text { to } 2.17\end{array}$ & 1.23 & 0.83 to 2.00 & $\begin{array}{l}1.21 \\
\star \\
\star \\
2.28 \\
\dagger\end{array}$ & 0.95 to 1.56 & $\begin{array}{l}1.01 \\
\star \\
1.93 \\
1.96 \\
\dagger\end{array}$ & $\begin{array}{l}0.77 \text { to } 1.33 \\
1.24 \text { to } 3.00 \\
1.45 \text { to } 2.39\end{array}$ & $\begin{array}{l}1.12 \\
0.87 \\
1.86 \\
1.15\end{array}$ & $\begin{array}{l}0.89 \text { to } 1.39 \\
0.34 \text { to } 2.24 \\
1.32 \text { to } 2.62 \\
0.83 \text { to } 1.60\end{array}$ & $\begin{array}{l}1.26 \\
8.04 \\
2.27 \\
2.30 \\
\dagger\end{array}$ & $\begin{array}{l}1.18 \text { to } 1.36 \\
6.82 \text { to } 9.47 \\
1.53 \text { to } 3.37 \\
1.84 \text { to } 2.88\end{array}$ \\
\hline MVT, all & $\begin{array}{l}\text { +E958.5, } \\
\text { E988.5 }\end{array}$ & 1.71 & 1.63 to 1.80 & 1.15 & 0.78 to 2.52 & 1.65 & 1.39 to 2.52 & 1.43 & 1.21 to 1.69 & 1.24 & 1.06 to 1.44 & 1.68 & 1.58 to 1.78 \\
\hline Pedestrian, other & $\begin{array}{l}\text { E800-E807 (.2) } \\
\text { E820-E825 (.7) } \\
\text { E826-E829 (.0) }\end{array}$ & 2.14 & 1.66 to 2.77 & * & & 2.60 & 1.83 to 8.56 & 1.45 & 0.60 to 3.49 & 3.16 & 1.50 to 6.68 & 1.38 & 0.80 to 2.37 \\
\hline $\begin{array}{l}\text { Firearm, all } \\
\text { Unintentional } \\
\text { Suicide } \\
\text { Homicide }\end{array}$ & $\begin{array}{l}\text { E922 } \\
\text { E955 (.0-.4) } \\
\text { E965 (.0-.4), } \\
\text { E970 }\end{array}$ & $\begin{array}{l}0.16 \\
0.40 \\
0.39 \\
0.03\end{array}$ & $\begin{array}{l}0.14 \text { to } 0.19 \\
0.28 \text { to } 0.58 \\
0.32 \text { to } 0.49 \\
0.02 \text { to } 0.05\end{array}$ & $\stackrel{\star}{\stackrel{\star}{*}} \underset{\star}{\mathrm{NA}}$ & & $\stackrel{\star}{\stackrel{\star}{*}}$ & & $\begin{array}{l}0.41 \\
\star \\
\star \\
\star\end{array}$ & 0.20 to 0.84 & $\begin{array}{l}0.18 \\
0.51 \\
\star \\
0.10\end{array}$ & $\begin{array}{l}0.11 \text { to } 0.29 \\
0.27 \text { to } 0.97 \\
0.04 \text { to } 0.23\end{array}$ & $\begin{array}{l}0.13 \\
0.28 \\
0.38 \\
0.01\end{array}$ & $\begin{array}{l}0.11 \text { to } 0.16 \\
0.17 \text { to } 0.47 \\
0.30 \text { to } 0.47 \\
0.01 \text { to } 0.03\end{array}$ \\
\hline Intent unknown & E985 (.0-.4) & 0.33 & 0.13 to 0.81 & * & & * & & * & & * & & 0.36 & 0.15 to 0.89 \\
\hline $\begin{array}{l}\text { Drowning } \\
\text { Unintentional }\end{array}$ & $\begin{array}{l}\text { E830, E832, } \\
\text { E910 }\end{array}$ & 1.51 & 1.34 to 1.70 & $\star$ & & 1.66 & 1.36 to 4.11 & 1.66 & 1.20 to 2.31 & 1.14 & 0.81 to 1.59 & 1.62 & 1.32 to 1.99 \\
\hline All & $\begin{array}{l}\text { +E954, E964, } \\
\text { E984 }\end{array}$ & 1.48 & 1.32 to 1.67 & $\star$ & & 1.59 & 1.31 to 4.04 & 1.67 & 1.21 to 2.31 & 1.11 & 0.79 to 1.56 & 1.65 & 1.35 to 2.01 \\
\hline $\begin{array}{l}\text { Fire/flame } \\
\text { Unintentional } \\
\text { All }\end{array}$ & $\begin{array}{l}\text { E890-E899 } \\
\text { +E958.1, } \\
\text { E968.0, E988.1 }\end{array}$ & $\begin{array}{l}0.58 \\
0.57\end{array}$ & $\begin{array}{l}0.47 \text { to } 0.71 \\
0.46 \text { to } 0.70\end{array}$ & $\begin{array}{l}0.42 \\
0.51\end{array}$ & $\begin{array}{l}0.20 \text { to } 1.23 \\
0.26 \text { to } 1.11\end{array}$ & $\begin{array}{l}0.50 \\
0.49\end{array}$ & $\begin{array}{l}0.37 \text { to } 1.23 \\
0.36 \text { to } 1.11\end{array}$ & $\begin{array}{l}0.52 \\
0.47\end{array}$ & $\begin{array}{l}0.31 \text { to } 0.86 \\
0.29 \text { to } 0.79\end{array}$ & $\begin{array}{l}0.62 \\
0.56\end{array}$ & $\begin{array}{l}0.30 \text { to } 1.27 \\
0.27 \text { to } 1.14\end{array}$ & $\begin{array}{l}1.45 \\
1.35\end{array}$ & $\begin{array}{l}0.91 \text { to } 2.31 \\
0.87 \text { to } 2.08\end{array}$ \\
\hline $\begin{array}{l}\text { Suffocation, all } \\
\text { Unintentional } \\
\text { Inhalation// } \\
\text { ingestion }\end{array}$ & E911-E912 & $\begin{array}{l}1.96 \\
1.30\end{array}$ & $\begin{array}{l}1.75 \text { to } 2.19 \\
0.96 \text { to } 1.77\end{array}$ & $\begin{array}{l}1.38 \\
2.37\end{array}$ & $\begin{array}{l}1.08 \text { to } 2.48 \\
1.56 \text { to } 1.98\end{array}$ & $\begin{array}{l}0.97 \\
0.88\end{array}$ & $\begin{array}{l}0.66 \text { to } 2.48 \\
0.48 \text { to } 1.98\end{array}$ & $\begin{array}{l}0.98 \\
\star\end{array}$ & 0.51 to 1.90 & $\begin{array}{l}1.79 \\
\star\end{array}$ & 1.30 to 2.44 & $\begin{array}{l}2.82 \\
\star\end{array}$ & 2.40 to 3.31 \\
\hline $\begin{array}{l}\text { Other } \\
\text { Suicide } \\
\text { Homicide } \\
\text { Intent unknown }\end{array}$ & $\begin{array}{l}\text { E913 } \\
\text { E953 } \\
\text { E963 } \\
\text { E983 }\end{array}$ & $\begin{array}{l}1.31 \\
3.71 \\
0.35 \\
1.23\end{array}$ & $\begin{array}{l}1.04 \text { to } 1.63 \\
3.17 \text { to } 4.35 \\
0.17 \text { to } 0.70 \\
0.55 \text { to } 2.74\end{array}$ & $\begin{array}{l}1.18 \\
\mathrm{NA} \\
0.91 \\
\star\end{array}$ & $\begin{array}{l}0.87 \text { to } 1.77 \\
0.32 \text { to } 0.98\end{array}$ & 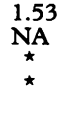 & 0.91 to 1.77 & $\begin{array}{l}1.17 \\
\star \\
\star\end{array}$ & 0.46 to 3.01 & $\begin{array}{l}2.18 \\
1.97 \\
\star \\
\star\end{array}$ & $\begin{array}{l}1.25 \text { to } 3.83 \\
1.27 \text { to } 3.04\end{array}$ & $\begin{array}{l}1.08 \\
3.63 \\
\star\end{array}$ & $\begin{array}{l}0.45 \text { to } 2.58 \\
3.06 \text { to } 4.31\end{array}$ \\
\hline $\begin{array}{l}\text { Falls } \\
\text { Unintentional }\end{array}$ & $\begin{array}{l}\text { E880-E886, } \\
\text { E888 }\end{array}$ & 2.23 & 1.73 to 2.89 & * & & 1.76 & 1.02 to 6.33 & 3.03 & 1.45 to 6.33 & 1.99 & 0.91 to 4.36 & 2.15 & 1.48 to 3.11 \\
\hline All & $\begin{array}{l}\text { +E957, E968.1, } \\
\text { E987 }\end{array}$ & 2.35 & 1.86 to 2.97 & * & & 1.79 & 1.05 to 6.68 & 3.33 & 1.63 to 6.80 & 2.11 & 1.04 to 4.28 & 2.25 & 1.64 to 3.10 \\
\hline $\begin{array}{l}\text { Cutting/piercing } \\
\text { Homicide } \\
\text { All }\end{array}$ & $\begin{array}{l}\text { E966, E974 } \\
\text { +E920, E956, } \\
\text { E986 }\end{array}$ & $\begin{array}{l}0.69 \\
0.83\end{array}$ & $\begin{array}{l}0.49 \text { to } 0.99 \\
0.60 \text { to } 1.14\end{array}$ & * & & $\begin{array}{l}4.54 \\
3.68\end{array}$ & $\begin{array}{l}1.88 \text { to } 6.68 \\
1.66 \text { to } 7.96\end{array}$ & $\stackrel{\star}{\star} .84$ & 1.32 to 6.14 & $\begin{array}{l}0.85 \\
0.99\end{array}$ & $\begin{array}{l}0.34 \text { to } 2.15 \\
0.42 \text { to } 2.34\end{array}$ & $\begin{array}{l}0.35 \\
0.39\end{array}$ & $\begin{array}{l}0.21 \text { to } 0.59 \\
0.24 \text { to } 0.63\end{array}$ \\
\hline $\begin{array}{l}\text { Poisoning, all } \\
\text { Unintentional } \\
\text { Suicide } \\
\text { Homicide } \\
\text { Intent unknown }\end{array}$ & $\begin{array}{l}\text { E850-E869 } \\
\text { E950-E952 } \\
\text { E962, E972 } \\
\text { E980-E982 }\end{array}$ & $\begin{array}{c}2.24 \\
1.24 \\
3.68 \\
\star \\
2.86\end{array}$ & $\begin{array}{l}1.89 \text { to } 2.64 \\
0.92 \text { to } 1.67 \\
2.91 \text { to } 4.64 \\
1.76 \text { to } 4.65\end{array}$ & 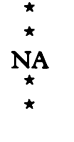 & & $\begin{array}{l}0.81 \\
1.00 \\
\text { NA } \\
\star\end{array}$ & $\begin{array}{l}0.39 \text { to } 9.27 \\
0.48 \text { to } 5.30\end{array}$ & $\begin{array}{l}\star \\
\star \\
\star \\
\star \\
\star\end{array}$ & & $\begin{array}{l}2.87 \\
2.32 \\
2.85 \\
\star \\
\star\end{array}$ & $\begin{array}{l}1.72 \text { to } 4.76 \\
1.09 \text { to } 4.93 \\
1.31 \text { to } 6.18\end{array}$ & $\begin{array}{l}2.44 \\
1.20 \\
3.27 \\
\star \\
3.56\end{array}$ & $\begin{array}{l}2.01 \text { to } 2.95 \\
0.81 \text { to } 1.78 \\
2.55 \text { to } 4.18 \\
2.07 \text { to } 6.12\end{array}$ \\
\hline $\begin{array}{l}\text { All } \\
\text { Unintentional } \\
\text { Suicide } \\
\text { Homicide } \\
\text { Intent unknown/ } \\
\text { other }\end{array}$ & $\begin{array}{l}\text { E800-E949 } \\
\text { E950-E959 } \\
\text { E960-E978 } \\
\text { E980-E999 }\end{array}$ & $\begin{array}{l}1.54 \\
1.41 \\
0.18 \\
0.93\end{array}$ & $\begin{array}{l}1.48 \text { to } 1.60 \\
1.28 \text { to } 1.56 \\
0.15 \text { to } 0.21 \\
0.67 \text { to } 1.28\end{array}$ & $\begin{array}{l}1.23 \\
\text { NA } \\
0.55 \\
\star\end{array}$ & $\begin{array}{l}1.04 \text { to } 1.82 \\
0.37 \text { to } 0.27\end{array}$ & $\begin{array}{l}1.37 \\
\mathrm{NA} \\
0.49 \\
\star\end{array}$ & $\begin{array}{l}1.24 \text { to } 1.82 \\
0.34 \text { to } 0.27\end{array}$ & $\begin{array}{l}1.34 \\
\star \star .56 \\
\star\end{array}$ & $\begin{array}{l}1.18 \text { to } 1.51 \\
0.33 \text { to } 0.95\end{array}$ & $\begin{array}{l}1.25 \\
0.91 \\
0.21 \\
1.16\end{array}$ & $\begin{array}{l}1.11 \text { to } 1.40 \\
0.65 \text { to } 1.25 \\
0.12 \text { to } 0.36 \\
0.52 \text { to } 2.58\end{array}$ & $\begin{array}{l}1.61 \\
1.30 \\
0.07 \\
1.31\end{array}$ & $\begin{array}{l}1.53 \text { to } 1.70 \\
1.17 \text { to } 1.44 \\
0.06 \text { to } 0.10 \\
0.90 \text { to } 1.90\end{array}$ \\
\hline
\end{tabular}

*Rates based on fewer than either 20 deaths (USA) or five deaths (NZ) are unstable and an asterisk is shown in place of a ratio.

$\dagger$ Data from the US National Highway Traffic Safety Administration suggest that most of the unspecified $(.9)$ traffic deaths involve vehicle occupants or motorcyclists. Therefore, in the calculation of rates, the 4th digit . 9 codes were proportionally distributed according to the known distribution of occupant and motorcyclists for each age group. With the NZ data the distribution was according to the information in the free text description of the injury event.

$\mathrm{CI}=$ confidence interval, NA = not applicable.

NZ were: MVTs $53 \%$, suffocation $11 \%$, drowning $9 \%$, and poisoning $5 \%$. For the USA the four leading causes were: MVTs $37 \%$, firearms $28 \%$, drowning $7 \%$, and suffocation $7 \% .^{1}$

Table 2 provides the rate ratios for $\mathrm{NZ}$ compared with the USA. NZ's total rate of child and adolescent injury is not substantially different from that of the USA. Reference to rates by intent reveals that NZ's unintentional and suicide rates are 1.6 and 1.3 times greater, respectively, than those for the USA. In contrast, the homicide rate for the USA is 5.5 times that for NZ.

When cause specific rates are examined, several major differences in unintentional injury are apparent. NZ's MVT rate is 1.72 times that of the USA. NZ rates exceed those of the USA's for nearly all types of road user and at all four age groups. Particularly notable in this respect are motorcycle crashes, where the death rates for 15-19 year olds are more than 10 times those of the USA.

In marked contrast is the situation relating to firearm injury death. Overall, the USA rate is more than six times that of NZ. A substantial contributor to this difference is the rate of firearm homicides in the USA for 10-14 and 15-19 year olds, the latter having a rate 100 times that of NZ! 
NZ fares less well in terms of drowning, where the rate is 1.5 times that for USA. This difference is consistent across three of the four age groups for which rates are presented.

$\mathrm{NZ}$ has half the rate of fire and flame deaths and this finding is consistent for all age groups except the 15-19 year old group where NZ rates exceed those for the USA.

NZ's rate for suffocation deaths is nearly twice that for the USA and most of this difference is due to deaths among those under 1 year old, in particular, those due to inhalation and ingestion, and suicide among teenagers. Similarly, NZ's fall and poisoning rates are in excess of twice those for the USA. In the latter instance, teenage suicide in NZ accounts for a significant portion of this experience.

\section{Discussion}

As indicated earlier the proposed groupings of causes of injury we used was recently developed in the USA. It represents a regrouping of the $\mathrm{E}$ codes of the $\mathrm{ICD}^{2}$ in that it seeks, at the first level, to group events by cause or mechanism and then, within these groupings, by intent. Such an approach is very useful for determining the significance, for example, of firearm deaths and drownings. The proposed matrix does not, however, have categories for all injury deaths, for example E919: unintentional injury due to machinery. We estimate that approximately $10 \%$ of the injury deaths in our series did not fall into any of the groupings. While this is not a substantial percentage, we note that there were 44 machinery deaths for the period we examined. This level of mortality is similar in size to deaths due to 'cutting/ piercing' for which a grouping is provided.

The proposed matrix was presented at a recent International Collaborative Effort on Injury Statistics meeting (Washington, 1996; unpublished). A focus of the discussions was the merit of enlarging the basic matrix to include injury types that either have a sizeable contribution to injury morbidity or which may be more relevant to countries other than the USA. As a consequence, the developers intend to produce a single matrix that will be suitable for both mortality and morbidity data, and include additional categories.

The data presented here show that NZ's injury mortality rate is not dissimilar to that for USA. However, when cause specific rates are examined, several major differences are evident. It is beyond the scope of this paper to examine in detail possible explanations for the differences but some speculation is warranted.

NZ's road traffic crash fatality toll compares unfavourably with the USA. This finding holds true for the total population as well, which suggests that there may be non-child specific factors which explain the differences such as a better standard of roads, and a more modern and safer vehicle fleet in the USA. Such factors would not appear to explain NZ's disproportionately high rate of motorcycle crashes. Could it be that there are significantly different usage patterns and this in turn results in differences in exposure both quantitatively and qualitatively? For example, are motorcycles used more often for day to day transport than is the case in the USA? Alternatively, the explanation could be much simpler, namefy under-reporting. In 1979 USA's Nation Center for Health Statistics, the source of the USA data used here, recorded substantial $\vec{F}$ fewer motorcycle deaths than the Fatal Accis dent Reporting System maintained by the Department of Transport. ${ }^{3}$

While this study has not provided detail o $\frac{\overline{0}}{8}$ the distribution of the types of firearm involve in the firearm homicides, other research has shown that handguns are an uncommon cause of firearm mortality in $\mathrm{NZ}^{4}{ }^{4}$ whereas they are $\overrightarrow{\mathrm{A}}$ very common cause in the USA. ${ }^{5}$ The exp planation which most readily comes to mind ta explain this situation is NZ's stricter handgut laws. Another possible explanation is that USA is a more violent society in all respects and that the firearm homicide rate simply reflects this The matrix used in this study does not permit the determination of the non-firearm homicid rates and thus a closer examination of th explanation.

The explanation for NZ's higher rate of unintentional drowning may lie in the high exposure to water coupled with high rates of participation in water based activity. A higher proportion of the $\mathrm{NZ}$ population may live io cities and towns which have harbours and eas access to the sea. Many NZ children and adolescents participate in water related activo ities. For example, among 15 year olds? swimming is the most frequently reported physical activity. In addition many participate in non-water activities that expose them to water (for example tramping (back packing) frequently requires the crossing of rivers). $\bar{E}$ would also appear that NZ youth spend greater number of hours participating in such activities. ${ }^{6}$

The USA's higher rate of fire and flame deaths may be attributable to a greater propof tion of the USA domestic housing stock being multistoried and constructed of more flam mable materials. Given that there is a relations ship between socioeconomic status and injury mortality and that the USA has greate extremes of poverty, which in turn is associate with substandard housing, then USA's higher rate is not unexpected. ${ }^{7}$

Without further disaggregation of the falls and suffocation data it is difficult to speculares on the possible reasons for the differences between the countries. For the latter cases the first author has previously undertaken a cure sory examination of the brief descriptions of the circumstances of death which are main tained on the mortality data base and has noted a number of references to cot death. The suggests that coding error may be a partial explanation for some of the difference.

NZ's higher rate of unintentional poisoning may be due in part to that fact that require ments for child resistant packaging are limite to drugs and then only a very limited range namely: aspirin, iron preparations, paracetamol, barbiturates, phenothiazines, tricyclic and tetracyclic and analogous antidepressants. This 
situation contrasts with the USA where a wider range of medical substances are covered and the requirements extend to other toxic solids and liquids.

NZ's high rate of teenage suicide has been a concern for sometime, especially since the male rate has been increasing over time. ${ }^{8}$ Factors which have been identified as being important in the NZ context and where NZ may differ from the USA include: provision of mental health services; protocols for the care of those known to be suicidal; support of family and friends; training programmes for those who work with youth; culturally appropriate policies, programmes, and services; the role of education and training institutions; and providing physically safe custodial environments. ${ }^{9}$

It should be emphasised that some of the differences which have been identified here may be attributable to variations between the countries in the criteria required by those certifying death to attribute it to a cause. Reference to the rate ratio for those deaths coded as 'intent unknown/other' does not support that hypothesis.

Alternatively, the standard of proof required for some specific causes of death may be higher in one of the countries. For example, could it be that medical examiners in the USA are more conservative than their counterparts in $\mathrm{NZ}$ in attributing death as due to suicide? Differences between the two countries in recording elderly injury mortality have been demonstrated. ${ }^{10}$

The fact that NZ performs poorly for many major causes of unintentional injury leads one to speculate on factors which may be having a more pervasive influence. It has been argued that the weight of evidence is strong that tort litigation has enhanced safety. ${ }^{11}$ The right to sue for injury damages was removed in $\mathrm{NZ}$ several years ago with the introduction of a nofault accident compensation scheme.

The theoretical potential for reducing injury in both countries is highlighted by applying specific rates from one country to the other. For example, if NZ had the unintentional injury rates of the USA we would save 96 lives each year. This would represent a $26 \%$ reduction in all injury deaths and a $32 \%$ reduction in unintentional injury deaths. Similarly, if the USA had NZ's homicide rate they would save 4149 lives a year. This would represent a $20 \%$ reduction in all injury deaths and an $82 \%$ reduction in homicide deaths.

The data presented here suggest areas for more detailed examination of statistics, coupled with a comparison of relevant injury prevention policies. In terms of the theoretical potential to reduce the injury mortality rate, priority must be given to $15-19$ year olds who account for $61 \%$ of all the deaths in NZ. Priorities for this age group are: MVTs (especially those involving occupants and motorcyclists), and suicide. Among the children, priorities are: MVT pedestrian and occupant deaths, and drownings. Among infants, the priority is suffocation.

While mortality experience is an important indicator of a country's child and adolescent health performance, in terms of injury, it is the 'tip of the iceberg'. For example, each year in NZ approximately 20000 children and teenagers receive hospital inpatient treatment for injury. It has been suggested that the disablement associated with some of these injuries is equally, if not more important. ${ }^{12}$ Similarly, from a health service provider perspective deaths are relatively cheap when compared with the cost of service provision to severely injured children requiring lifelong care. When setting priorities for injury research and prevention, it is necessary to balance the rank order and absolute contributions made by different categories of injury to mortality and morbidity.

The Injury Prevention Research Unit is jointly funded by the Accident Rehabilitation and Compensation Insurance Corporation, and the Health Research Council of New Zealand. The tion, and the Health Research Council of New Zealand. The injury statistics were provided by the New Zealand Health
Information Service. The authors wish to acknowledge the advice of Lois Fingerhut, Elizabeth McLoughlin, and David advice of Lois Fingerhut, Elizabeth McLo
Chalmers, in the preparation of this paper.

1 Fingerhut LA, Annest $\mathrm{JL}$, Baker SP, Kochanek $\mathrm{KD}$, McLoughlin E. Injury mortality among children and teenagers in the United States, 1993. Injury Prevention 1996; 2: $93-4$

2 World Health Organisation. International classification of disease. 9th Revision. Geneva: World Health Organisation, 1977.

3 Trinca GW, Johnston IR, Campbell BJ, et al. Reducing traffic injury - a global challenge. Melbourne: Royal Australasian College of Surgeons, 1988 .

4 Norton R, Langley J. Firearm related deaths in New Zealand 1978-87. NZ Med f 1993; 106: 463-5.

5 Hargarten S, Karlson T, O'Brien M, Hancock J, Quebbeman $\mathrm{E}$. Characteristics of firearms involved in fatalities.
margarten man E. Characteristics of

6 Reeder AI, Stanton WR, Langley JD, Chalmers DJ Adolescents' sporting and leisure time physical activities during their 15 th year. Canadian fournal of Sports Science 1991; 16: $308-15$.

7 Baker SP, O'Neill B, Ginsburg MJ, Li G. The injury fact book. 2nd Ed. New York: Oxford University Press, 1992.

8 Barwick H. Youth suicide prevention project: workshop report and literature review. Wellington: Department of Health, and liter 1993.

9 Ministry of Health. Youth mental health and suicide prevention: report and recommendations of the steering group Wellington: Ministry of Health, 1994.

10 Langlois JA, Smith GS, Baker SP, Langley JD. International comparisons of injury mortality in the elderly: issues and differences between New Zealand and the United States. Int $\mathcal{F}$ Epidemiol 1995; 24: 136-43.

11 Teret SP, Jacobs M. Prevention and torts: the role of litigation in injury control. Law, Medicine and Health Car 1989; 17: $17-22$.

12 Miller TR, Pindus NM, Douglass JB, Rossman SB Databook on nonfatal injury: incidence, costs, and consequences. Washington, DC: The Urban Institute Press, 1995. 